\title{
Implantação da Preleção como Acolhimento da Equipe: Relato de Caso
}

\author{
Nisivoccia, Patricia; Bova, Rosangela \\ Hospital Geral de Pedreira — patricia.silva@pedreira.org.br
}

Introdução: a unidade de terapia intensiva neonatal é um ambiente que proporciona stress pelo alto grau de complexidade técnica e gravidade dos pacientes, acometendo tanto a equipe multiprofissional envolvida e os pais dos recém nascidos internados. a equipe depara freqüentemente com situações que necessitam de controle emocional. no âmbito hospitalar a equipe multiprofissional cuida do paciente, dos pertences do paciente, da alimentação, da família, dos documentos, das roupas, da temperatura do ambiente, do exame a ser feito e assim por diante. São vários os momentos enquanto exercermos o cuidar que nos vemos obrigados a enfrentar situações estressantes e que mexem com os nossos sentimentos, no setor de terapia intensiva neonatal a equipe convive com a perda freqüente. para resolver o conflito de maneira positiva desenvolvemos uma metodologia naquele setor que proporcionasse um momento diário de reflexão, discussão de casos, leitura motivacional e acolhimento diante de situações pessoais que interferem no desempenho da equipe proporcionando um ambiente agradável para equipe, paciente e familiar. Objetivos: Relatar experiência exitosa na implantação do acolhimento diário da equipe multiprofissional através de preleção, bem como analisar a viabilidade operacional e seus benefícios. Métodos: Esse estudo consistiu em um relato de experiência da implantação da preleção motivacional em uma unidade de terapia intensiva neonatal de um hospital escola secundário, sendo que o setor foi escolhido aleatoriamente. 0 acolhimento agregado a preleção foi feito após o recebimento do plantão, onde a equipe em forma em forma de circulo se reuniu durante 15 minutos para alinhar metas do dia, rever pendências anteriores, partilhar experiências ou angustias pessoais e realizar leitura e reflexação de texto motivacional. Resultados: Durante e após a implantação diária do acolhimento no inicio do plantão, houve relatos positivos da equipe enfermagem, médica, fisioterapia, fonoaudióloga e nutrição com melhora substancial na assistência prestada, traduzido em números através dos indicadores de absenteísmo, turnover, elogios dos pais e na redução dos indicadores assistências de qualidade. Conclusões: Evidenciamos que a experiência foi exitosa com melhora na interação entre o grupo, interesse em compartilhar as experiências, melhora no clima e trabalho em equipe, redução do absenteísmo e turnover e comunicação eficaz. com resultado concluímos que o acolhimento apresenta benefícios na humanização da equipe e supera as dificuldades impostas pela implantação, sendo uma ferramenta eficaz e sem custo.

Nisivoccia, Patricia; Bova, Rosangela. Implantação da Preleção como Acolhimento da Equipe: Relato de Caso. In: Anais do Congresso Internacional de Humanidades \& Humanização em Saúde [= Blucher Medical Proceedings, num.2, vol.1]. São Paulo: Editora Blucher, 2014. ISSN 2357-7282

DOI 10.5151/medpro-cihhs-10787 